\title{
Episcopal Farmworker Ministry and disaster response to COVID-19
}

\author{
Lariza Garzon a* \\ Episcopal Farmworker Ministry \\ Andrew R. Smolski b \\ North Carolina State University
}
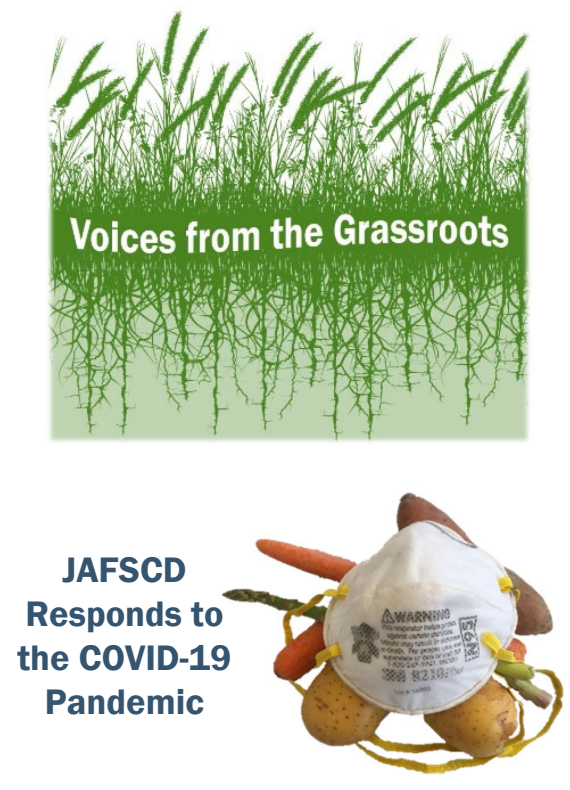

Submitted June 1, 2020 / Published online June 25, 2020

Citation: Garzon, L., \& Smolski, A R. (2020). Episcopal Farmworker Ministry and disaster response to COVID-19. Journal of Agriculture, Food Systems, and Community Development, 9(4), 191-196. https://doi.org/10.5304/jafscd.2020.094.002

Copyright (C) 2020 by the Authors. Published by the Lyson Center for Civic Agriculture and Food Systems. Open access under CC-BY license.

$\mathrm{F}$ armworkers in the U.S. confront numerous challenges. They receive poverty wages and have high rates of wage theft, precarious immigration status, and a high risk of injury and fatality (Smolski, 2019). They also face rampant food insecurity, with 40 to 70 percent of farmworkers experiencing a lack of reliable access to nutritious meals (Minkoff-Zern, 2014). Add to these challenges poor mental health from social isolation for guest workers who hold $\mathrm{H} 2-\mathrm{A}$ visas for agricultural work, the potential of working under dangerous and abusive conditions, and substandard housing. The general picture is of a workforce vulnerable to exploitation that does not

a* Corresponding author: Lariza Garzon, Executive Director, Episcopal Farmworker Ministry; 2989 Easy Street; Dunn, NC 28334 USA; +1-910-567-6917; lariza@efwm.org

b Andrew R. Smolski, Doctoral Candidate, Department of Sociology and Anthropology, North Carolina State University; arsmolsk@,ncsu.edu receive the same benefits and protections as other workers due to agriculture's exemption from many labor regulations. These challenges have been exacerbated by the current pandemic, which has hit farmworker communities particularly hard (North Carolina Department of Health and Human Services [NC DHHS], 2020; Wozniacka, 2020).

Episcopal Farmworker Ministry (EFWM) is on the front lines of addressing these challenges. EFWM is a joint ministry of the Episcopal Diocese of North Carolina and the Episcopal Diocese of East Carolina. EFWM provides direct services, leadership development programs, and educational and advocacy programs aimed toward a systemic change of the policies that affect farmworkers and their families. Located in Dunn, North Carolina, EFWM has four staff members who work in the North Carolina community. In this Voices from the Grassroots essay, we highlight challenges and EFWM's strategies for supporting farmworkers during the COVID-19 pandemic crisis. 
A major challenge for EFWM currently is conducting outreach to H-2A farmworkers. Outreach is important to provide information about rights, distribute donations, tell workers about the various resources and services available to them, and provide information about pesticide exposure and heat-related illnesses. During the pandemic, outreach is also important to inform workers about how to access health care, basic information about the virus, and what they should do if they think that they are sick with the virus. Farmworkers are especially vulnerable because they live in congregate housing that does not offer private rooms or bathrooms. Farmworker camps can consist of a small group of people or groups of hundreds of people. Lack of information about the virus, medical centers, and workers' rights amid the pandemic can increase the capacity for COVID-19 to spread through farmworker communities. Because many farmworkers come to the United States to make money to support themselves and their families in their home country, they have an incentive to work through their illness. Additionally, there is solidarity among workers, whereby they do not want to cause a quarantine of workers that would amplify the economic loss. Farmworkers do have the right to up to 80 hours of COVID-19-related sick pay or paid leave to take care of a sick family member. But employers with fewer than 50 employees can apply for an exemption from paid family leave, and it is unclear how widely known and used paid leave is by farmworkers.

The risk is further amplified by a lack of personal protective equipment (PPE) for farmworkers. And, even with adequate PPE, there is a need for training on how to use PPE properly and how to protect one's health while living and working in congregate living settings. With farmworkers often in multigenerational, multifamily, or worker barrack living conditions - in close quarters and with high occupancy-housing can become a hotspot for the spread of COVID-19. As of June 5, 2020,

\section{Figure 1. The Episcopal Farmworker Ministry (EFWM) Facility in Dunn, North Carolina}



Photo courtesy of Episcopal Farmworker Ministry. 
five migrant farmworker housing facilities in North Carolina had COVID-19 outbreaks (NC DHHS, 2020). According to our current understanding, NC DHHS only reports outbreaks, defined as two or more cases in a congregate living facility and only in migrant labor camps with more than 10 occupants. That is problematic, because of 1,877 migrant labor camps in the state, 1,011 are certified for fewer than 10 occupants. Thus, current reports most likely underestimate the current level of COVID-19 in farmworker communities.

Another challenge is that there is less work for farmworker communities because growers have been changing their hiring practices in order to implement physical distance and planting fewer crops due to economic uncertainty. This has made growers more willing to hire $\mathrm{H}-2 \mathrm{~A}$ guest workers, over whom they have more contractual control, leaving seasonal and undocumented workers with little or no work. The solution of preventing workers from getting sick by having fewer workers and increasing physical distance has meant increasing levels of social isolation for guest workers, who often work Monday until Saturday, with only Sunday as a time to leave the labor camp.

By reducing freedom of movement, social isolation can negatively affect farmworkers' ability to purchase and consume food. Some of the workers cannot leave labor camps and may have to rely on a person appointed to purchase food, food sales through labor contractors, or food sales organized by growers. This is problematic because of a history of abuse around food sales, with issues arising over poor food quality, loss of money, more isolation, and less control over their own lives. All of this can lead to increased food insecurity and heightened stress.

EFWM is confronting the crisis and these challenges through a disaster management response

\section{Figure 2. Food Distribution to Families}

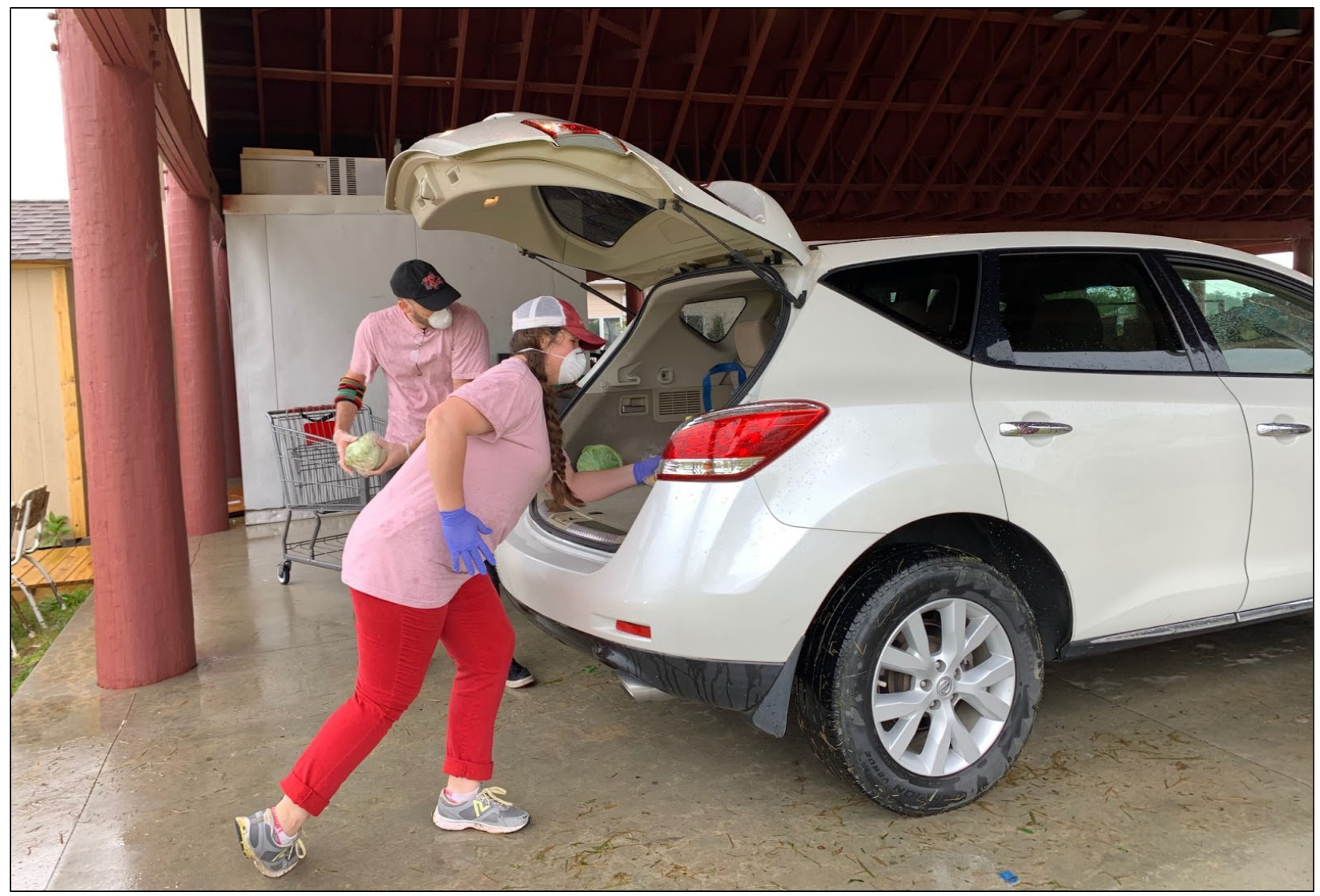

Photo courtesy of Episcopal Farmworker Ministry. 
model. That model involves four action areas to assist and $\mathrm{H}-2 \mathrm{~A}$ workers and families:

1. Mitigation: For future pandemics, this could involve advocating for policies such as building codes and housing standards that address the spread of infectious diseases.

2. Preparedness: Outreach, education, and training carried out via phone calls, mass text messages, printed materials, remote trainings, videos, and social media.

3. Response: Free mental health services in Spanish, food distribution, and an emergency fund to support farmworker families.

4. Recovery: Adaptation of services for sustained recovery and planning for future disasters.

The disaster management model is based on experiences from the hurricanes that frequent North Carolina. During those catastrophes, similar problems arise, such as food insecurity and eco- nomic loss. Two important disaster response interventions have been the distribution of food and emergency financial aid to the farmworker community.

Food distribution has been carried out in two ways. The first is through a biweekly distribution from EFWM facilities to 250 families. The recipients line up in their cars, and no one gets out of their vehicle. Instead, they unlock their trunks, and food boxes are placed in them. This helps to maintain physical distance. EFWM staff and volunteers wear PPE to reduce the possibility of further contagion. Another food distribution method has been direct drop-offs to farmworkers, operating with similar safety measures in place for social distancing. As noted, farmworkers are often isolated at labor camps without cars and limited time off, making this on-site distribution an important strategy. Instead of directly distributing to farmworkers, the boxes are stacked by EFWM and then the farmworkers retrieve them. $\mathrm{H}-2 \mathrm{~A}$ workers have had some difficulties purchasing large quantities of food and hygiene items, and some of them have

\section{Figure 3. Food Distribution to Farmworkers}



Photo courtesy of Episcopal Farmworker Ministry. 


\section{Figure 4. Volunteers During the Pandemic}

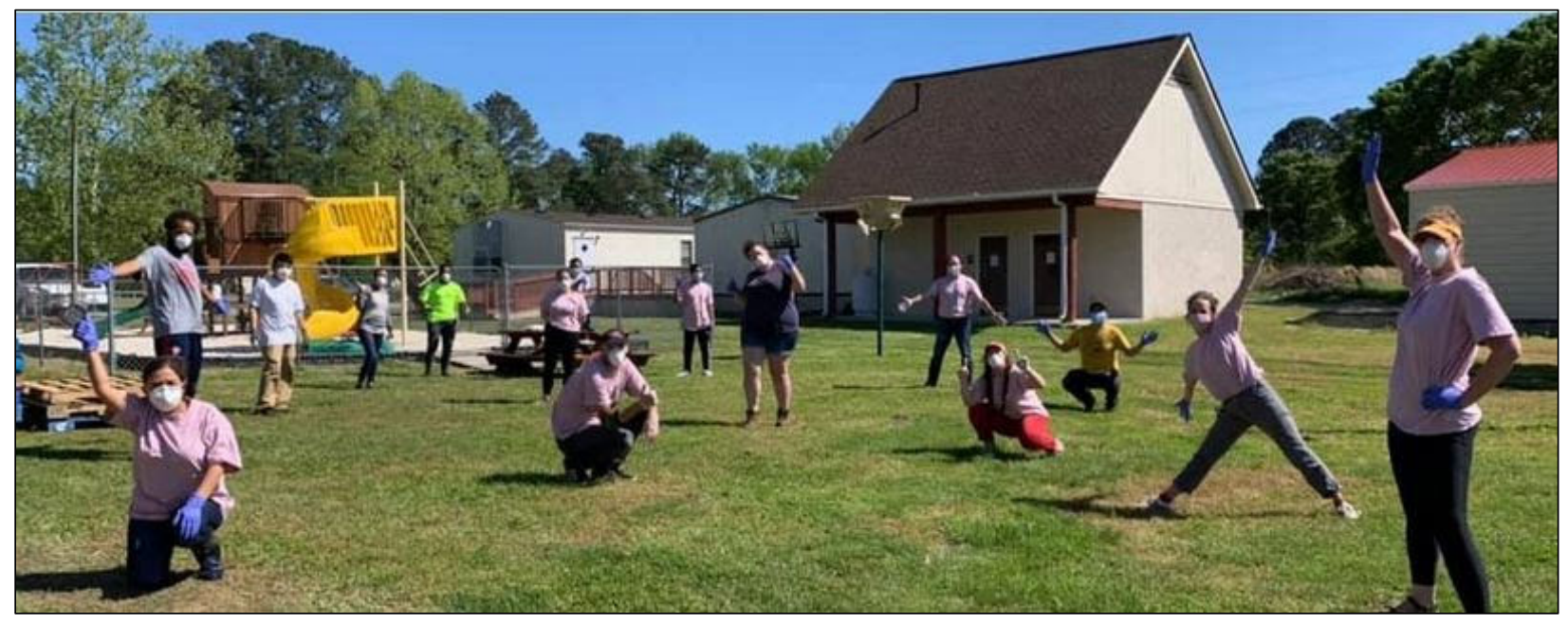

Photo courtesy of Episcopal Farmworker Ministry.

not had much work either. Thus, the distribution of food has become a key activity in addressing the increasing food insecurity in agriculture worker communities due to the pandemic's impacts on supply chains and financial well-being.

The emergency financial aid supports guest workers and undocumented people, who are the majority of farm laborers (USDA, 2020), and who have been largely excluded from stimulus payments and unemployment benefits. That exclusion is part of a larger agricultural exceptionalism, with farmworkers often not included in rules that protect workers in other industries, such as those pertaining to minimum wage, overtime, the right to organize without retaliation, unemployment, and child labor laws (Rodman et al., 2016). In a sense, what the pandemic has done is to highlight this inequity. During the pandemic, farmworkers who have not been getting work due to changes in grower hiring practices or those who are quarantined and do not get paid sick days are in a very precarious economic situation. EFWM has carried out a fundraiser to disburse financial aid to agriculture workers and their families, raising US $\$ 60,000$ as of this writing. This financial aid is a form of nonprofit economic stimulus-a stand-in for failures in public policy, themselves the result of neoliberalization's decades-long negative effect on the social safety net.

EFWM has risen to meet the crisis within its means and with prior experience in disaster response. It is part of a network of organizations in North Carolina, through the Farmworker Advocacy Network and North Carolina's Council of Churches, working to bring about safe places to live, safe places to work, strengthening labor protections, and strong enforcement of our existing laws (Farmworker Advocacy Network, n.d.). We must recognize that farmworkers are essential workers, whose labor provides society its most fundamental element: food. Essential protections, services, and benefits should be provided to this population.

For more information about the Episcopal Farmworker Ministry or to donate to support its work, visit https://episcopalfarmworkerministry.org/.

\section{References}

Farmworker Advocacy Network. (n.d.). About. Retrieved June 18, 2020, from https://ncfan.org/about/

Minkoff-Zern, L.-A. (2014). Hunger amidst plenty: Farmworker food insecurity and coping strategies in California. Local Environment, 19(2), 204-219. https://doi.org/10.1080/13549839.2012.729568

North Carolina Department of Health and Human Services. (2020, June 5). COVID-19 ongoing outbreaks in congregate living settings: Updated June 5, 2020. Retrieved from https://covid19.ncdhhs.gov/dashboard/outbreaks-and-clusters 
Rodman, S. O., Barry, C. L., Clayton, M. L., Frattaroli, S., Neff, R. A., \& Rutkow, L. Agricultural exceptionalism at the state level: Characterization of wage and hour laws for U.S. farmworkers. Journal of Agriculture, Food Systems, and Community Development, 6(2), 89-110. https://doi.org/10.5304/jafscd.2016.062.013

Smolski, A. R. (2019). Stemming the exploitation of immigrant farm labor. Contexts, 18(2), 70-71. https://doi.org/10.1177\%2F1536504219854727

U.S. Department of Agriculture. (2020, April 22). Farm labor. Retrieved from https://www.ers.usda.gov/topics/farm-economy/farm-labor/

Wozniacka, G. (2020, May 13). As hundreds of farmworkers test positive for COVID-19, many remain unprotected [Blog post]. Civil Eats. Retrieved from https://civileats.com/2020/05/13/as-hundreds-of-farmworkers-testpositive-for-covid-19-many-remain-unprotected/ 